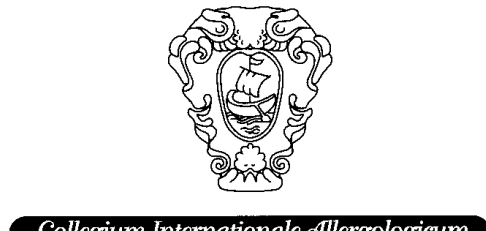

Collegium Internationale Allergologicum

22nd Symposium

September 12-16, 1998

Corfu, Hellas

\section{From Molecular Science to the Treatment of Allergy}

22nd Symposium of the Collegium Internationale

Allergologicum,

September 12-16, 1998, Corfu, Greece

Editors

A. Togias, Baltimore, Md.

K. Kontou-Fili, Athens

106 figures, 8 in color, and 68 tables, 1999
Basel $\cdot$ Freiburg $\cdot$ Paris $\cdot$ London $\cdot$ New York .

New Delhi $\cdot$ Bangkok $\cdot$ Singapore $\cdot$ Tokyo $\cdot$ Sydney 
S. Karger

Medical and Scientific Publishers

Basel $\cdot$ Freiburg $\cdot$ Paris $\cdot$ London

New York $\cdot$ New Delhi $\cdot$ Bangkok

Singapore $\cdot$ Tokyo $\cdot$ Sydney
Drug Dosage

The authors and the publisher have exerted every effort to ensure that drug selection and dosage set forth in this text are in accord with current recommendations and practice at the time of publication. However, in view of ongoing research, changes in government regulations, and the constant flow of information relating to drug therapy and drug reactions, the reader is urged to check the package insert for each drug for any change urged to check the package insert for each drug for any change
in indications and dosage and for added warnings and precauin indications and dosage and for added warnings and precau-
tions. This is particularly important when the recommended agent is a new and/or infrequently employed drug.
All rights reserved

No part of this publication may be translated into other languages, reproduced or utilized in any form or by any means, electronic or mechanical, including photocopying, recording, microcopying, or by any information storage and retrieval system, without permission in writing from the publisher or, in system, without permission in writing from the publisher or, in
the case of photocopying, direct payment of a specified fee to the Copyright Clearance Center (see 'General Information').

(c) Copyright 1999 by S. Karger AG,

P.O. Box, CH-4009 Basel (Switzerland)

Printed in Switzerland on acid-free paper by

Reinhardt Druck, Basel

ISBN 3-8055-6875-4

\section{KARGER}

Fax+4161306 1234

E-Mail karger@karger.ch

www.karger.com 
International Archìes of

Allergy $_{\text {and }}$

Immunology

\section{The Paul Kallós Memorial Lecture}

87 Mechanisms and Pharmacologic Control of Basophil-Derived IL-4 and IL-13

Schroeder, J.T.; MacGlashan, D.W., Jr.; Lichtenstein, L.M. (Baltimore, Md.)

Biology of Inflammatory Products: Cytokines

90 Role of the Th2 Cytokines in the Development of Allergen-Induced Airway Inflammation and Hyperresponsiveness

Hamelmann, E. (Berlin/Denver, Colo.); Wahn, U. (Berlin); Gelfand, E.W. (Denver, Colo.)

95 Expression of Th1 and Th2 Immunoregulatory Cytokines by Human Eosinophils

Woerly, G.; Roger, N.; Loiseau, S.; Capron, M. (Lille)

98 Eosinophil Development and Bone Marrow and Tissue Eosinophils in Atopic Asthma

Robinson, D.S.; North, J.; Zeibecoglou, K.; Ying, S.; Meng, Q.; Rankin, S. (London); Hamid, Q. (Montreal); Tavernier, J. (Gent); Kay, A.B. (London)

101 Regulation of IL-5 and IL-5 Receptor Expression in the Bone Marrow of Allergic Asthmatics

Denburg, J.A.; Sehmi, R.; Upham, J.; Wood, L.; Gauvreau, G.; O'Byrne, P. (Hamilton)

104 Stem Cell Factor-Dependent Survival, Proliferation and Enhanced Releasability of Purified Mature Mast Cells Isolated from Human Intestinal Tissue

Bischoff, S.C.; Sellge, G.; Schwengberg, S.; Lorentz, A.;

Manns, M.P. (Hannover)

108 TNF- $\alpha$ and IL-5 Gene Induction in IgE plus AntigenStimulated Mast Cells Require Common and Distinct Signaling Pathways

Baumruker, T.; Csonga, R.; Jaksche, D.; Novotny, V.;

Prieschl, E.E. (Vienna)

The Peter Dukor Memorial Lecture

112 IgE Inhibition as a Therapy for Allergic Disease

Jardieu, P.M.; Fick, R.B., Jr. (South San Francisco, Calif.)

Experimental Therapeutics (A)

116 An in vitro Model for the Allergen-IgE-FceRI Interaction Laffer, S. (Vienna); Hogbom, E.; Adrianson, J.; Grönlund, H. (Uppsala); Sillaber, C.; Valent, P. (Vienna); Vangelista, L. (Heidelberg); Kricek, F.; Kraft, D.; Valenta, R. (Vienna)

119 Mimotope and Anti-Idiotypic Vaccines to Induce an Anti-lgE Response

Stadler, B.M.; Zürcher, A.W.; Miescher, S. (Bern); Kricek, F. (Vienna); Vogel, M. (Bern)
122 Linked Suppression in Peripheral T Cell Tolerance to the House Dust Mite Derived Allergen Der $p 1$

Hoyne, G.F. (Edinburgh); Dallman, M.J. (London); Lamb, J.R. (Edinburgh)

125 Differential Recognition of Recombinant Phl p 5 Isoallergens by Phl p 5-Specific T Cells

van Neerven, R.J.J.; Wissenbach, M.; Ipsen, H. (Hørsholm); Bufe, A. (Borstel); Arnved, J. (Copenhagen); Würtzen, P.A. (Hørsholm)

129 Modulation of an Allergic Immune Response via the Mucosal Route in a Murine Model of Inhalative Type-I Allergy

Wiedermann, U.; Jahn-Schmid, B.; Repa, A.; Kraft, D.; Ebner, C (Vienna)

The Evolving Role of T Cells in Allergic Disease

133 T Cells and Chronic Asthma

Kon, O.M.; Kay, A.B. (London)

136 Cloned Th Cells Confer Eosinophilic Inflammation and Bronchial Hyperresponsiveness

Kaminuma, O. (Tokyo/Saitama); Mori, A. (Tokyo/Kanagawa); Ogawa, K. (Tokyo/Saitama); Nakata, A.; Kikkawa, H.; Ikezawa, K. (Saitama); Okudaira, H. (Tokyo)

140 Regulation of Allergic Inflammation by Skin-Homing T Cells in Allergic Eczema

Akdis, C.A.; Akdis, M.; Simon, H.-U.; Blaser, K. (Davos)

145 A New Paradigm of T Cell Allergy: Requirement for the B-1 Cell Subset

Askenase, P.W.; Kawikova, I.; Paliwal, V.; Akahira-Azuma, M. (New Haven, Conn.); Gerard, C. (Boston, Mass.); Hugli, T. (La Jolla, Calif.); Tsuji, R. (Noda)

Neuro-Immune Interactions

150 Allergen-Induced Sensory Neuroplasticity in Airways Undem, B.J.; Hunter, D.D.; Liu, M. (Baltimore, Md.); Haak-Frendscho, M.; Oakragly, A. (Madison, Wisc.); Fischer, A. (Giessen)

154 Neural Hyperresponsiveness and Nerve Growth Factor in Allergic Rhinitis

Sanico, A.M.; Koliatsos, V.E. (Baltimore, Md.); Stanisz, A.M.; Bienenstock, J. (Hamilton); Togias, A. (Baltimore, Md.)

159 Nerve Growth Factor: An Important Molecule in Allergic Inflammation and Tissue Remodelling Bonini, S.; Lambiase, A.; Bonini, S. (Rome); Levi-Schaffer, F. (Jerusalem); Aloe, L. (Rome)

163 Neurotrophins: A Link between Airway Inflammation and Airway Smooth Muscle Contractility in Asthma? Braun, A.; Lommatzsch, M.; Lewin, G.R. (Berlin); Virchow, J.C. (Freiburg); Renz, H. (Berlin)

\section{KARGER \\ (c) 1999 S. Karger AG, Base}

Fax+4 41613061234

E-Mail karger@karger.ch

www.karger.com
Access to full text and tables of contents,

including tentative ones for forthcoming issues:

www.karger.com/journals/iaa/iaa_bk.htm 
166 Effects of Inflammatory Neuropeptides on the Arachidonate Cascade of Platelets

Gecse, Á; Kis, B.; Mezei, Z.; Telegdy, G. (Szeged)

The Carl Prausnitz Memorial Lecture

171 The Importance of Recombinant Allergens for Diagnosis and Therapy of IgE-Mediated Allergies Kraft, D. (Vienna); Ferreira, F. (Salzburg); Vrtala, S.; Breiteneder, H.; Ebner, C.; Valenta, R. (Vienna); Susani, M.; Breitenbach, M. (Salzburg); Scheiner, O. (Vienna)

Regulation of Cellular Activation (A)

177 gp49B1 and Its Related Family of Counterregulatory Receptors of the Immunoglobulin Superfamily Katz, H.R. (Boston, Mass.)

180 Novel CD8 Molecule on Macrophages and Mast Cells: Expression, Function and Signaling

Hirji, N.S.; Lin, T.-J.; Gilchrist, M.; Nault, G.; Nohara, O.; Grill, B.J.; Belosevic, M. ; Stenton, G.R. (Edmonton); Schreiber, A.D. (Philadelphia, Pa.); Befus, A.D. (Edmonton)

Novel Concepts on Inflammatory Cells and Immunoglobulins

183 Role of the Eosinophil in Protein Oxidation in Asthma: Possible Effects on Proteinase/Antiproteinase Balance Foreman, R.C.; Mercer, P.F. (Southampton); Kroegel, C. (Jena); Warner, J.A. (Southampton)

187 The Apparent Monovalency of Human IgG4 Is Due to Bispecificity

Aalberse, R.C.; Schuurman, J.; van Ree, R. (Amsterdam)

190 Expression of a Human IgG4 Antibody, BAB2, with Specificity for the Major Birch Pollen Allergen, Bet v 1 in Escherichia coli: Recombinant BAB2 Fabs Enhance the Allergic Reaction

Eibensteiner, P. (Vienna); Denépoux, S. (Dardilly);

Steinberger, P.; Kraft, D. (Vienna); Visco, V. (Dardilly); Banchereau, J. (Dallas, Tex.); Lebecque, S. (Dardilly); Valenta, R. (Vienna)

193 IgE-Mediated Reactions to Autoantigens in Allergic Diseases

Appenzeller, U.; Meyer, C. (Davos); Menz, G. (Davos-Wolfgang); Blaser, K.; Crameri, R. (Davos)

197 Endogenous Superallergen Protein Fv Interacts with the $V_{H} 3$ Region of IgE to Induce Cytokine Secretion from Human Basophils

Patella, V.; Giuliano, A.; Florio, G. (Naples); Bouvet, J.-P. (Paris); Marone, G. (Naples)

Mast Cell Biology

200 Secretory Phospholipase $A_{2}$ : A Putative Mediator of Airway Inflammation

De Marino, V.; Gentile, M.; Granata, F.; Marone, G.;

Triggiani, M. (Naples)
202 Eosinophils Activate Mast Cells to Release Histamine Piliponsky, A.M.; Pickholtz, D. (Jerusalem); Gleich, G.J. (Rochester, Minn.); Levi-Schaffer, F. (Jerusalem)

204 Interaction of Human Mast Cell Tryptase with Endothelial Cells to Stimulate Inflammatory Cell Recruitment

Compton, S.J.; Cairns, J.A.; Holgate, S.T.; Walls, A.F. (Southampton)

206 Comparison of Genetic and Immunohistochemical Findings in Childhood and Adult Onset Urticaria Pigmentosa

Büttner, C. (Berlin); Grabbe, J. (Lübeck); Haas, N. (Berlin); Sepp, N.T. (Innsbruck); Kunkel, G.; Henz, B.M. (Berlin)

Allergen Testing and Immunotherapy: Current and Future Approaches

208 Lessons from the Antibody Recognition of the Major Timothy Grass Pollen Allergen Phl p 1 Ball, T. (Vienna); Fuchs, T. (Göttingen); Kraft, D.; Valenta, R. (Vienna)

210 Do Tr1 Cells Play a Role in Immunotherapy? Saloga, J.; Bellinghausen, I.; Knop, J. (Mainz)

212 Perspective of Purified Natural and Recombinant Allergens in Diagnosis and Treatment of Inhalant Allergies

van Ree, R.; van Leeuwen, A. (Amsterdam); Bond, J. (Waltham, Mass.); Aalberse, R. (Amsterdam)

214 Comparison of T-Cell Responses Induced by Major and Less Major Allergens of the House Dust Mite Thomas, W.R.; Hales, B.J.; Shen, H.-D.; Smith, W. (West Perth)

216 Clinical Evaluation of Genetically Engineered Hypoallergenic rBet $\mathbf{1}$ Derivatives Pauli, G.; Purohit, A.; Oster, J.P.; de Blay, F. (Strasbourg); Vrtala, S.; Niederberger, V.; Kraft, D.; Valenta, R. (Vienna)

218 Genetic Engineering of Recombinant Hypoallergenic Oligomers of the Major Birch Pollen Allergen, Bet v1: Candidates for Specific Immunotherapy

Vrtala, S.; Hirtenlehner, K. (Vienna); Susani, M. (Salzburg); Hufnagl, P.; Binder, B.R. (Vienna); Vangelista, L.; Pastore, A. (Heidelberg); Sperr, W.R.; Valent, P.; Ebner, C.; Kraft, D.; Valenta, R. (Vienna)

220 Clinical Testing of Recombinant Allergens of the Mold Alternaria alternata

Unger, A.; Stöger, P.; Simon-Nobbe, B.; Susani, M. (Salzburg); Crameri, R. (Davos); Ebner, C. (Vienna); Hintner, H.; Breitenbach, M. (Salzburg)

222 IgE-Related Peptide Mimotopes. Basic Structures for Anti-Allergy Vaccine Development

Kricek, F.; Ruf, C. (Vienna); Rudolf, M.P. (Bern); Effenberger, F.; Mayer, P. (Vienna); Stadler, B.M. (Bern)

224 Nonapeptides Selected by Phage Display Mimic the Binding Sites of Monoclonal Antibodies BIP1 and BIP4 on Bet $v$ 1, the Major Birch Pollen Allergen

Jensen-Jarolim, E.; Ganglberger, E.; Leitner, A.; Radauer, C.; Scheiner, O.; Breiteneder, H. (Vienna) 
Food Allergy, Atopic Dermatitis

226 The Expression of IL-4, IL-6 and TNF- $\alpha$ in the Liver of Food-Sensitized Mice after Oral Challenge

Sakamoto, Y.; Ueno, K.; Yofu, S.; Fujita, K.; Iikura, Y. (Tokyo)

228 Nutritive Casein Formula Elicits Pseudoallergic Skin Reactions by Prick Testing

Kurek, M. (Gdánsk); Mał aczyńska, T. (Gdánsk-Oliwa)

230 Evidence for a Birch Pollen-Specific Cutaneous T-Cell Response in Food-Responsive Atopic Dermatitis Werfel, T.; Reekers, R.; Busche, M.; Schmidt, P.; Constien, A.; Wittmann, M.; Kapp, A. (Hannover)

232 Oral Provocation Tests with Food Additives in Atopic Eczema

Vieluf, D. (Borkum); Wieben, A. (Hamburg); Ring J. (Munich)

234 Significant Delay of Apoptosis and Fas Resistance in Eosinophils of Subjects with Intrinsic and Extrinsic Type of Atopic Dermatitis

Wedi, B.; Raap, U.; Kapp, A. (Hannover)

236 Anti-Inflammatory Activity in Human Skin: It Prevents Edema Formation in vitro

Dorsch, W. (Mainz); Suttorp, N. (Giessen); Lottspeich, F. (Munich); Zepp, F. (Mainz)

240 Contribution of Bacterial Superantigens to Atopic Dermatitis

Herz, U.; Bunikowski, R.; Mielke, M.; Renz, H. (Berlin)

Epidemiology of Atopic Conditions

242 Allergography of Salomvar, Hungary. Preliminary Results

Nekam, K. (Budapest); Andrasofszky, Z. (Mosdos); Gönczi, Z.; Tornoczi, L. (Budapest); Papp, G. (Salomvar); Gyeney, L.; Viranyi, M. (Budapest)

245 Prevalence and Severity of Asthma and Wheezing in an Adolescent Population

Baena-Cagnani, C.E.; Patiño, C.M.; Cuello, M.N.; Minervini, M.C; Fernández, A.M.; Garip, E.A.; Salvucci, K.D.; Sancho, M.L.; Corelli, S.; Gómez, R.M. (Córdoba)

247 Allergy to Betalactams. Where Are We Going? Patriarca, G.; D'Ambrosio, C.; Schiavino, D.; Nucera, E.; Sun, J.Y.; Del Ninno, M.; Misuraca, C.; Buonomo, A. (Rome)

251 Frequency of Immediate-Type Food Allergy in Children in Japan

Iikura, Y.; Imai, Y.; Imai, T.; Akasawa, A.; Fujita, A.; Hoshiyama, K.; Nakura, H.; Kohno, Y.; Koike, K.; Okudaira, H.; Iwasaki, E. (Tokyo)

253 Clinical Assessment of Latex Allergy among Hospital Health Care Providers

DuBuske, L; Babahkin, A.; Cieslewicz, G (Boston, Mass.).; Nolte, H. (Copenhagen); Sheffer, A.L. (Boston, Mass.)

\section{Granulocyte Biology}

255 Localization of Eosinophil-Derived Neurotoxin and Eosinophil Cationic Protein in Neutrophilic Leukocytes Sur, S. (Rochester, Minn.); Glitz, D.G. (Los Angeles, Calif.); Kita, H. (Rochester, Minn.); Kujawa, S.M. (Los Angeles, Calif.); Peterson, E.A.; Weiler, D.A.; Kephart, G.M.; Wagner, J.M. ; George, T.J.; Gleich, G.J.; Leiferman, K.M. (Rochester, Minn.)

259 Hemin and Carbon Monoxide Modulate the Immunological Response of Human Basophils Mirabella, C.; Baronti, R; Berni, L.A.; Gai, P.; Ndisang, J.F.; Masini, E.; Mannaioni, P.F. (Florence)

261 Apoptosis in Inflammatory Diseases Simon, H.-U. (Davos)

$263 \alpha d \beta 2$ Integrin Is a Ligand for Vascular Cell Adhesion Molecule-1

Grayson, M.H. (Baltimore, Md.); Van der Vieren, M. (Bothell, Wash.); Sterbinsky, S.A. (Baltimore, Md.); Gallantin, W.M.; Hoffman, P.; Staunton, D. (Bothell, Wash.); Bochner, B.S. (Baltimore, Md.)

The David Marsh Memorial Symposium: Candidate Genes and Gene Regulation in Allergic Disease

265 Candidate Gene and Mutational Analysis in Asthma and Atopy

Wilkinson, J.; Thomas, N.S.; Morton, N.; Holgate, S.T.

(Southampton)

268 Promoter Polymorphism in the Candidate Genes, IL-4, IL-9, TGF- $\beta 1$, for Atopy and Asthma

Rosenwasser, L.J. (Denver, Colo.)

271 Regulatory Mechanisms of Human T Cell IL-5 Synthesis: Differential Roles of the Proximal Promoter-Binding Proteins in IL-5 Gene Transcription Mori, A. (Sagamihara); Kaminuma, O.; Ogawa, K. (Saitama); Kobayashi, N. (Tokyo); Akiyama, K. (Sagamihara); Okudaira, H. (Tokyo)

275 Genetic Determinants of 5-Lipoxygenase Transcription

Drazen, J.M.; Silverman, E.S. (Boston, Mass.)

279 Analysis of $\gamma 4$ Germline Transcription in Human B Cells

Agresti, A.; Vercelli, D. (Milan)

282 Positional Candidate Gene Approach and Functional Genomics Strategy in Atopy Gene Discovery

Nickel, R.G.; Saitta, F.P.; Freidhoff, L.R.; Yu, X.Y.; Ehrlich, E.; Barnes, K.C.; Beaty, T.; Huang, S.K. (Baltimore, Md.)

IgE: Roles, Regulation, Receptors

285 Role of IgE for the Onset of Allergic Cutaneous Response Caused by Simple Chemical Hapten in Mice Nagai, H.; Inagaki, N.; Tanaka, H. (Gifu)

287 Allergic Respiratory Responses to Der $p 1$ in Mice Clarke, A.H.; O’Brien, R.M.; Rolland, J.M.; Thomas, W.R. (Footscray/Prahan/Perth)

Int Arch Allergy Immunol Vol. 118, No. 2-4, 1999 
289 CD8 T-Lymphocyte-Mediated Regulation of Ovalbumin-Specific Murine IgE Responses Thomas, M.J.; MacAry, P.A.; Kemeny, D.M. (London)

292 IgE Downmodulates Stem Cell Factor-Driven Mast Cell Development from Cultured Peripheral Blood Mononuclear Cells

Welker, P.; Grabbe, J.; Zuberbier, T.; Henz, B.M. (Berlin)

294 Regulation of FceRI Expression on Monocytic Cell Lines

Dubois, G.R.; Reischl, I.G.; Peiritsch, S.; Brown, K.; Wheat, L.; Effenberger, F.; Woisetschläger, M.; Mudde, G.C. (Vienna)

296 A Novel Regulatory Mechanism for FceRI Expression on Human Primary Monocytes

Reischl, I.G.; Semper, A.E. (Southampton); Mudde, G.C. (Fresnes); Church, M.K. (Southampton)

Isolation and Characterization of Allergens

298 Corn Allergens: IgE Antibody Reactivity and CrossReactivity with Rice, Soy, and Peanut

Lehrer, S.B.; Reese, G. (New Orleans, La.); Malo, J.-L. (Montreal); Lahoud, C.; Leong-Kee, S. (New Orleans, La.); Goldberg, B. (Kanagawa); Carle, T. (New Orleans, La.); Ebisawa, M. (Kanagawa)

300 IgE-Binding Epitopes of Shrimp Tropomyosin, the Major Allergen Pen a 1 Reese, G.; Ayuso, R.; Carle, T.; Lehrer, S.B. (New Orleans, La.)

302 Isolation of Basidiomycete Allergens Brander, K.A.; Pichler, W.J.; Helbling, A. (Bern)

304 Characterization of Recombinant Bet v 4, a Birch Pollen Allergen with Two EF-Hand Calcium-Binding Domains

Ferreira, F.; Engel, E.; Briza, P.; Richter, K. (Salzburg); Ebner, C. (Vienna); Breitenbach, M. (Salzburg)

306 Molecular and Immunological Characterization of Carp Parvalbumin, a Major Fish Allergen

Bugajska-Schretter, A. (Vienna); Pastore, A. (London); Vangelista, L. (Heidelberg); Rumpold, H.; Valenta, R.; Spitzauer, S. (Vienna)

309 Cloning of the Patatin-Like Latex Allergen Hev b 7, Its Expression in the Yeast Pichia pastoris and Its Immunological Characterization Breiteneder, H.; Sowka, S.; Wagner, S.; Krebitz, M.; Hafner, C.; Kinaciyan, T. (Vienna); Yeang, H.Y. (Kuala Lumpur); Scheiner, O. (Vienna)

311 Cloning and Molecular Characterization of Hev b 3, a Spina-bifida-Associated Allergen from Hevea Brasiliensis Latex

Scheiner, O.; Wagner, B.; Wagner, S.; Krebitz, M. (Vienna); Crameri, R. (Davos); Niggemann, B. (Berlin); Yeang, H.Y. (Kuala Lumpur/Sungei Buloh); Ebner C.; Breiteneder, H. (Vienna)

313 Modification of a Major Peanut Allergen Leads to Loss of IgE Binding

Burks, A.W.; King, N.; Bannon, G.A. (Little Rock, Ark.)
315 Tertiary Structure and Biophysical Properties of a Major Peanut Allergen, Implications for the Production of a Hypoallergenic Protein

Bannon, G.A.; Shin, D.; Maleki, S.; Kopper, R.; Burks, A.W. (Little Rock, Ark.)

Factors Affecting Atopy, Allergic Responses, and Airway Function

317 Cat-Specific IgA Antibodies in Breast Milk from Atopic and Non-Atopic Mothers: Detection of Fel d 1-IgG Immune Complexes in Cord Blood and Sera Casas, R.; Björkstén, B. (Linköping)

319 Cytokines in Breast Milk from Allergic and Nonallergic Mothers

Fagerås Böttcher, M.; Jenmalm, M.C. (Linköping); Garofalo, R.P. (Galveston, Tex.) Björkstén, B. (Linköping)

321 Polyunsaturated Fatty Acids in Breast Milk in Relation to Atopy in the Mother and Her Child

Duchén, K.; Yu, G.; Björkstén, B. (Linköping)

324 Validation of Family Sampling for Mite Allergen (Der p 1) Exposure

Carswell, F; Al-Dabbagh M.; Hunt, L.; Carswell, A.J. (Bristol)

326 Seasonal Variation in Concentrations of Mite Allergen (Der p 1) in the Mattress

Carswell, F.; Al-Dabbagh, M; Carswell, A.J.; Hunt, L.; Almquist, C. (Bristol)

328 Chemical Nature of Antioxidant Complement Activators in Allergenic Extracts

Berrens, L.; González Romano, M.L. (Madrid)

330 Is Complement Activation a Factor in Bronchial Asthma?

Glovsky, M.M. (Pasadena, Calif.); Lukacs, N.; Ward, P.A. (Ann Arbor, Mich.)

333 Ozone-Induced Release of Histamine in Human Nasal Mucosa of Smokers and Nonsmokers in Organ Culture Schierhorn, K.; Zhang, M.; Matthias, C.; Kunkel, G. (Berlin)

Current Treatment Modalities for Rhinitis and Asthma

335 Consumption of Antihistamines and Antiasthmatics in Hungary during 1992-1996

Szemere, P.A.; Viczián, Á.; Szepezdi, Zs.; György, L.; Paál, T. (Budapest)

338 Sudies into the Possible Central Effects of the H-1 Receptor Antagonist, Fexofenadine

Stone, B.M.; Turner, C.; Mills, S.L.; Nicholson, A.N. (Farnborough)

339 A Comparison of Cetirizine, Ebastine, Epinastine, Fexofenadine, Terfenadine, and Loratadine versus Placebo in Suppressing the Cutaneous Response to Histamine

Grant, J.A. (Galveston, Tex.); Danielson, L.; Rihoux, J.-P.; DeVos, C. (Braine-l'Alleud) 
341 Changes in Inflammatory Cells and Airway Remodeling after Beclomethasone Dipropionate Administration

Sano, Y.; To, Y.; Ogawa, C.; Otomo, M.; Suzuki, N.; Ito, K. (Tokyo)

343 Theophylline Decreases Sputum Eosinophilia of Asthmatics

Louis, R.; Bettiol, J.; Cataldo, D.; Radermecker, M. (Liège)

345 Comparison of an Inhaled Corticosteroid (Triamcinolone Acetonide) to a Long-Acting Bronchodilator (Salmeterol), the Combination, and Placebo in Mild-Moderate Adult Asthmatic Patients Creticos, P.S.; Freidhoff, L.R. (Baltimore, Md.); Bernstein, D.I. (Cincinnati, Ohio); Chu, T. (San Jose, Calif.);

Khattignavong, A.P.; Pasatiempo, A.M. (Baltimore, Md.); Lim, J.C. (Collegeville, Pa.)

347 Clinical Outcome of Combination Therapy by Anti-Allergic Drugs in Adult Patients with Bronchial Asthma

Nakagawa, T.; Nakamura, T. (Kawasaki); Suzuki, H.; Narushima, M.; Akizawa, T.; Ohtsuka, H.; Endo, S.; Odagiri S.; Takahashi, H.; Yoshiike, Y.; Suzuki, S.; Miyashita, A. (Yokohama); Akiyama, K.; Miyamoto, T. (Kanagawa)

T-Lymphocyte and Monocyte/Macrophage Biology

349 Recurrent Vulvovaginal Candidiasis - Allergy or Immune Deficiency?

Clancy, R.; Corrigan, E.; Dunkley, M.; Eyers, F.; Beagley, K. (Newcastle)

351 Prostaglandin E2 Inhibits SEB-Mediated Induction of the Cutaneous Lymphocyte-Associated Antigen Santamaria, L.F.; Torres, R.; Ryder, H.; Beleta, J.; Palacios, J.M. (Barcelona)

353 Histidine Decarboxylase Expression in Human Monocytes, Macrophages and Macrophage Subsets Belke, K.; Baron, J.; Schmutzler, W.; Zwadlo-Klarwasser, G. (Aachen)

355 Preferential Expression of the Skin-Homing Receptor CLA in Peripheral T Lymphocytes from Patients with Drug-Allergic Reactions

Leyva, L.; Torres, M.J.; Posadas, S.; Luque, I.; Gonzalez, L.; Blanca, M.; Juarez, C.; Santamaria, L.F. (Malaga)

358 Multiple Cytochrome P450-Isoenzymes mRNA Are Expressed in Dendritic Cells

Sieben, S.; Baron, J.M.; Blömeke, B.; Merk, H.F. (Aachen)

Diagnostic Methodologies

362 In vivo Leukocytes Labeling Using a Platelet Factor 4Derived Heparin Binding Peptide Technetium Complex Nicodemus, C.F.; Moyer; B.R.; Lister-James, J. (Londonderry, N.H.)

364 Antigen-Specific Sulphidoleukotriene Production in Allergy to Beta-Lactam Antibiotics

Sanz, M.L.; Sánchez, G.; Vila, L.; Diéguez, I; Oehling, A.K. (Pamplona)
366 The Real Value of IgG4 Determination in Immunotherapy Follow-Up

Oehling, A.; Sanz, M.L.; Resano, A. (Pamplona)

368 Antibodies to Commercially Available Interferon-Beta Molecules in Multiple Sclerosis Patients Treated with Natural Interferon-Beta

Mayorga, C.; Luque, G.; Romero, F.; Guerrero, R.; Blanca, M.; Fernandez, O. (Malaga)

Clinical Allergy: Rhinitis and Asthma

372 Sinusitis and Acute Asthma in Adults

Peters, E.; Crater, S.; Phillips, C.D.; Wheatley, L.M.; Platts-Mills, T.A.E. (Charlottesville, Va.)

375 Regulation of Proinflammatory Cytokines in Seasonal Allergic Rhinitis

Bachert, C.; van Kempen, M.; Van Cauwenberge, P. (Ghent)

380 Hypothetical Mechanisms of Action of an $\mathrm{H}_{\mathbf{1}}$-Antihistamine in Asthma

Rihoux, J.P. (Braine-l'Alleud); Michel L. (Paris); Arnold, R. (Bochum); König, W. (Bochum/Magdeburg)

Th1/Th2 Regulation

384 OX40-Mediated Cosignal Enhances the Maturation of Naive Human CD4+ T Cells into High IL-4-Producing Effectors

Delespesse, G.; Ohshima, Y.; Yang, L.-P.; Demeure, C.; Sarfati, M. (Montreal)

387 IP-10 Mediated Reinforcement of Human Type 1 Cytokine Synthesis to Environmental Allergens among Non-Atopic Subjects

Gangur, V.; Simons, F.E.R.; HayGlass, K.T. (Winnipeg)

391 IL-10 Induces a Th2 Cell Tolerance in Allergic Asthma Adachi, M.; Oda, N.; Kokubu, F.; Minoguchi, K. (Tokyo)

395 T-Cell Function in Atopic Children Jenmalm, M.C. (Linköping)

399 Do Allergens Induce Type-2 Immune Responses? Comoy, E.; Pestel, J. (Lille); Stewart, G.A. (Perth); Finkelman, F. (Cincinnati, Ohio); Capron, A. ; Thyphronitis, G. (Lille)

Risk Factors for Atopy and Specific Sensitization

403 Environmental Risk Factors for Respiratory and Skin Atopy: Results from Epidemiological Studies in Former East and West Germany

Ring, J. (Munich); Krämer, U. (Düsseldorf); Schäfer, T.; Abeck, D. (Munich); Vieluf, D. (Hamburg); Behrendt, H. (Munich/Düsseldorf/Hamburg)

408 Is Enhanced Fetal Growth a Risk Factor for the Development of Atopy or Asthma? Beasley, R.; Leadbitter, P.; Pearce, N.; Crane, J. (Wellington) 
411 Implications of the Grass Group I Allergens on the Sensitization and Provocation Process

Petersen, A.; Grobe, K.; Schramm, G. (Borstel); Vieths, S. (Langen); Altmann, F. (Wien); Schlaak, M; Becker, W.-M. (Borstel)

414 Timothy Grass (Phleum pratense L.) Pollen as Allergen Carriers and Initiators of an Allergic Response

Behrendt, H.; Tomczok, J.; Sliwa-Tomczok, W.; Kasche, A.; Ebner von Eschenbach, C. (Munich); Becker, W.M. (Borstel); Ring, J. (Munich)

Biology of Inflammatory Products: Cytokines and Mediators

419 Cloning of the Human Homolog of Mouse Transmembrane Tryptase

Wong, G.W.; Tang, Y.; Stevens, R.L. (Boston, Mass.)

422 Novel Autocrine and Paracrine Loops of the Stem Cell Factor/Chymase Network

de Paulis, A.; Minopoli, G.; Dal Piaz, F.; Pucci, P.; Russo, T.; Marone, G. (Naples)

426 Cytotoxic Properties of Eosinophil Granule Major Basic Protein for Tumor Cells

Kubo, H.; Loegering, D.A.; Adolphson, C.R.; Gleich, G.J. (Rochester, Minn.)

429 Matrix Metalloproteinase-9 in Myeloid Cells: Implications for Allergic Inflammation

Hayashi, M.; Schellenberg, R.R.; Tsang, S.; Roberts, C.R. (Vancouver)

433 IL-4 Inhibits Human CD8 T Cell Expression of the Common IL-2 Receptor Gamma Chain

Vyas, B.; Vukmanovic-Stejic, M.; Noble, A.; Kemeny, D.M. (London)

437 Differences between Cytokine Release from Bronchial Epithelial Cells of Asthmatic Patients and NonAsthmatic Subjects: Effect of Exposure to Diesel Exhaust Particles

Devalia, J.L.; Bayram, H.; Abdelaziz M.M.; Sapsford, R.J.; Davies, R.J. (London)
Regulation of Cellular Activation (B)

440 Regulation of FceRI Synthesis in Human Eosinophils Bjerke, T.; Hoffmann, H.J.; Christensen, E.I.; Poulsen, L.K.; Skjold, T.; Dahl, R. (Aarhus)

443 Signal Transduction through Interferon-Gamma Receptor on Human Eosinophils Ochiai, K.; Ishihara, C.; Tomioka, H. (Sakura)

447 Effects of Interferon- $\gamma$ on Mobilization and Release of Eosinophil-Derived RANTES

Velazquez, J.R.; Lacy, P.; Mahmudi-Azer, S.; Moqbel, R. (Edmonton)

450 Cytoplasmic Lipid Bodies in Eosinophils: Central Roles in Eicosanoid Generation

Weller, P.F.; Bozza, P.T.; Yu, W.; Dvorak, A.M. (Boston, Mass.)

Experimental Therapeutics (B)

453 DNA-Based Immunization for Asthma

Broide, D.; Raz, E. (La Jolla, Calif.)

457 Bacterial DNA and CpG-Containing Oligodeoxynucleotides Activate Cutaneous Dendritic Cells and Induce IL-12 Production: Implications for the Augmentation of Th1 Responses Jakob, T.; Walker, P.S. (Bethesda, Md.); Krieg, A.M. (Iowa City, Iowa); von Stebut, E.; Udey, M.C.; Vogel, J.C. (Bethesda, Md.)

462 The CC Chemokine Receptor Antagonist Met-RANTES Inhibits Eosinophil Effector Functions

Elsner, J.; Petering, H.; Kimmig, D. (Hannover); Wells, T.N.C.; Proudfoot, A.E.J. (Geneva); Kapp, A. (Hannover)

466 Author Index Vol. 118, No. 2-4, 1999

469 Subject Index Vol. 118, No. 2-4, 1999

472 Author Index Vol. 118, 1999

472 Subject Index Vol. 118, 1999

after 472 Contents Vol. 118, 1999 